\title{
Structure and function of rhizosphere and non-rhizosphere soil microbial community respond differently to elevated ozone in field-planted wheat
}

\author{
Zhan Chen ${ }^{1}$, Xiaoke Wang ${ }^{2, *}$, He Shang ${ }^{1}$
}

1. Institute of Forest Ecology, Environment and Protection, Chinese Academy of Forestry, Key Laboratory of Forest Ecology and Environment, State Forestry Administration, Beijing 100091, China. Email: chenchen323@163.com

2. State Key Laboratory of Urban and Regional Ecology, Research Center for Eco-Environmental Sciences, Chinese Academy of Sciences, Beijing 100085, China

\section{A R T I C L E I N F O}

\section{Article history:}

Received 19 August 2014

Revised 23 December 2014

Accepted 23 December 2014

Available online 21 April 2015

\section{Keywords:}

$\mathrm{O}_{3}$

Wheat

Rhizosphere soil

Non-rhizosphere soil

CLPP

PLFA

\begin{abstract}
A B S T R A C T
To assess the responses of the soil microbial community to chronic ozone $\left(\mathrm{O}_{3}\right)$, wheat seedlings (Triticum aestivum Linn.) were planted in the field and exposed to elevated $\mathrm{O}_{3}\left(\mathrm{eO}_{3}\right)$ concentration. Three treatments were employed: (1) Control treatment (CK), AOT40 =0; (2) $\mathrm{O}_{3}-1$, AOT40 $=1.59 \mathrm{ppm} \bullet \mathrm{h}$; (3) $\mathrm{O}_{3}-2$, AOT40 $=9.17 \mathrm{ppm} \bullet \mathrm{h}$. Soil samples were collected for the assessment of microbial biomass C, community-level physiological profiles (CLPPs), and phospholipid fatty acids (PLFAs). $\mathrm{EO}_{3}$ concentration significantly reduced soil microbial carbon and changed microbial CLPPs in rhizosphere soil, but not in non-rhizosphere soil. The results of the PLFAs showed that $\mathrm{eO}_{3}$ concentrations had significant effects on soil community structure in both rhizosphere and non-rhizosphere soils. The relative abundances of fungal and actinomycetous indicator PLFAs decreased in both rhizosphere and non-rhizosphere soils, while those of bacterial PLFAs increased. Thus the results proved that $\mathrm{eO}_{3}$ concentration significantly changed the soil microbial community function and composition, which would influence the soil nutrient supply and carbon dynamics under $\mathrm{O}_{3}$ exposure.
\end{abstract}

(c) 2015 The Research Center for Eco-Environmental Sciences, Chinese Academy of Sciences. Published by Elsevier B.V.

\section{Introduction}

In the troposphere, particularly at the surface of the earth, $\mathrm{O}_{3}$ is a widespread phytotoxic air pollutant. $\mathrm{O}_{3}$ has been shown to be harmful to human health, vegetation and certain materials (Bytnerowicz et al., 2007; Serengil et al., 2011). Background concentrations of $\mathrm{O}_{3}$ in the troposphere have continuously increased since the preindustrial age, although control measures on the emission of its precursors have reduced $\mathrm{O}_{3}$ peaks (Vingarzan, 2004; Derwent et al., 2007). China has undergone rapid industrialization and urbanization in recent decades. Information on ground level $\mathrm{O}_{3}$ concentrations in China is limited, but the available data suggest that these concentrations may attain potentially damaging levels, exceeding the Chinese National Air Quality Standard (based on U.S. standards) of $80 \mathrm{~nL} / \mathrm{L}$ for many hours during the summer (Zheng et al., 1998; Chen et al., 2013).

Current ambient $\mathrm{O}_{3}$ levels may cause severe effects on plants, including visible foliar injury or growth reduction, impairment of physiological traits and impacts on resource allocation and reproduction (Paoletti, 2007; Feng et al., 2008; Zhang et al., 2011; Niu et al., 2011; Chen et al., 2008). In recent

\footnotetext{
* Corresponding author. E-mail: wangxk@rcees.ac.cn (Xiaoke Wang).
} 
years, considerable (or increasing) attention has been paid to the below-ground effects of $\mathrm{eO}_{3}$ (Chen et al., 2009). This is because plants live in close association and interaction with soil microorganisms, particularly in their rhizospheres and during the decay of plant material (Kogel-Knabner, 2002). $\mathrm{EO}_{3}$ not only causes losses to crop yield but can also significantly reduce the allocation of assimilates into the root. This reduction in root biomass would influence the entry of organic matter into the soil (Andersen, 2003). $\mathrm{EO}_{3}$ reduces litter quality and rates of decay. The types and amounts of organic root exudates can be changed when the shoots are exposed to high levels of $\mathrm{O}_{3}$, and these changes may affect rhizosphere microbial activity, potentially altering the ecological and nutritional dynamics in the rhizosphere (McCrady and Andersen, 2000).

In the few cases where soil microbial community responses to $\mathrm{O}_{3}$ stress have been examined, these responses have been variable. The effects of $\mathrm{eO}_{3}$ on microbial functional diversity of both the rhizosphere and bulk soil in potted wheat were analyzed by using CLPPs, which showed that $\mathrm{eO}_{3}$ significantly affected the carbon degradative microbes in rhizosphere soil, while not in bulk soil (Chen et al., 2009). CLPP and PLFA analyses showed that carbon degradative microbes and the microbial structure of surface soil under paddy rice were altered in response to $\mathrm{eO}_{3}$, and PLFAs showed much more change than CLPPs (Chen et al., 2010). Seven meadow species were exposed to $\mathrm{eO}_{3}$ for three growing seasons, and the PLFA results of bulk soil showed that bacterial, actinobacterial, and fungal PLFAs and the fungal:bacterial PLFA ratio were decreased (Kanerva et al., 2008). In the same study, the decrease in the total microbial PLFA biomass in the bulk soil of Lathyrus pratensis under $\mathrm{eO}_{3}$ and eCO 2 (elevated $\mathrm{CO}_{2}$ ) (both $p=0.050$ ) arose from reductions in the PLFA biomass of indicator subgroups for actinobacteria (29\% and $31 \%$ ), bacteria (26\% and $33 \%$ ) and mycorrhiza (i.e., AM fungi) (31\% and 35\%) in particular. Active fungal biomass in bulk soil of Agrostis capillaris was also significantly reduced under $\mathrm{eO}_{3}$ and $\mathrm{CO}_{2}$ combined (21\%), while this significant effect of $\mathrm{O}_{3}$ and $\mathrm{CO}_{2}$ was not found in the rhizosphere soil (Manninen et al., 2010). This insignificant effect of $\mathrm{O}_{3}$ on the overall functional structure of rhizosphere soil was also found in winter wheat, using an $\mathrm{O}_{3}$ FACE fumigation system (Li et al., 2013). In the study, functional genes in the wheat rhizosphere microbial community were analyzed using GeoChip 3.0, which showed that the overall functional diversity and structure of the rhizosphere microbial community appeared not to be significantly altered by $\mathrm{eO}_{3}$ $(60 \mathrm{~nL} / \mathrm{L})$, while the results showed that the abundance of specific functional genes involved in $\mathrm{C}$ fixation and degradation, nitrogen $(\mathrm{N})$ fixation, and sulfite reduction did significantly $(p<0.05)$ alter in response to $\mathrm{eO}_{3}$ (Li et al., 2013). These results showing no significant effect of $\mathrm{O}_{3}$ on the rhizosphere soil microbial community were in contradiction with common knowledge, which holds that $\mathrm{eO}_{3}$ affects the rhizosphere soil microbial community much more than bulk soil.

Wheat (T. aestivum Linn.) is one of the most $\mathrm{O}_{3}$-sensitive crops and is among the most important crops in China. Ground-level $\mathrm{O}_{3}$ pollution has already decreased global wheat yields by $8.5 \%$ to $14 \%$ (Wilkinson et al., 2012). A previous meta-analysis indicated that $\mathrm{eO}_{3}$ decreases wheat grain yield, grain weight, grain number per ear, ear number per plant and harvest index by $26 \%, 18 \%, 11 \%, 5 \%$ and $11 \%$, respectively, relative to ambient air (Feng et al., 2009). Our previous results have shown that $\mathrm{eO}_{3}$ levels may alter microbial community function in the rhizosphere soil, but not in the bulk soil, under potted wheat (Chen et al., 2009). However, it remains unclear how the soil microbial community under field-planted wheat responds to $\mathrm{eO}_{3}$ and if this response is the same as that observed under potted wheat.

In this study, we hypothesize: (1) that soil carbon degradative microbes and soil microbial community structure would alter after wheat is exposed to $\mathrm{eO}_{3}$; (2) that the effects of $\mathrm{eO}_{3}$ on the rhizosphere soil community are more significant than for non-rhizosphere soil; and (3) that PLFA analysis could discriminate more differences between rhizosphere and non-rhizosphere soil community response to $\mathrm{eO}_{3}$ than CLPPs. To test these hypotheses, both rhizosphere and non-rhizosphere soils of field-planted wheat were analyzed for CLPPs and PLFAs.

\section{Materials and methods}

\subsection{Experimental site}

The experimental site was located at the Shuangqiao Farm $\left(31^{\circ} 53^{\prime} \mathrm{N}, 121^{\circ} 18^{\prime} \mathrm{E}\right)$ in Jiaxing City, Zhejiang Province, approximately $100 \mathrm{~km}$ from Shanghai, China's largest city. This site is in the center of the Yangtze Delta and represents one of the most important crop production areas in China. The area is influenced by the Asian monsoon climate system, with cold, dry winters and warm, wet summers. Mean temperature and annual precipitation are $15.5^{\circ} \mathrm{C}$ and $1199 \mathrm{~mm}$, respectively. The prevailing cultivation rotations are wheat-rice and rape-rice.

\subsection{Crop management}

On 15 November, 2006, wheat (T. aestivum L. Jia 002) seeds were sown in the field. Open-top chambers were placed on blocks on 20 March, 2007. These plots consisted of three rows, with four plots in each row. Protective belts of approximately $3 \mathrm{~m}$ in width were established between the plots. Before transplanting, $60 \mathrm{~kg} /$ ha pure nitrogen (N), $60 \mathrm{~kg} / \mathrm{ha}_{2} \mathrm{O}_{5}$ and $60 \mathrm{~kg} / \mathrm{ha} \mathrm{K}_{2} \mathrm{O}$ were applied, and $69.3 \mathrm{~kg} / \mathrm{h}$ a pure $\mathrm{N}$ was reapplied during the tillering stage and the jointing stage. The crops were harvested on 28 May.

\section{3. $\mathrm{O}_{3}$ exposure and experimental design}

The experiments were conducted in closed octagonal open-top chambers (OTCs), $2 \mathrm{~m}$ in diameter and $2.2 \mathrm{~m}$ in height. The boxes were connected to filter boxes, either without filters or with activated charcoal and a fan, and run at two air changes per minute.

An improved, innovative $\mathrm{O}_{3}$ distribution system was employed in this study. A rotatable transparent pipe with many small holes (diameter of $10 \mathrm{~mm}$ at intervals of $10 \mathrm{~cm}$ ) released either charcoal-filtered air ( $\mathrm{CF}$ air) or $\mathrm{O}_{3}$ above the crop canopy. The $\mathrm{CF}$ air or the $\mathrm{O}_{3}+\mathrm{CF}$ air was driven from a centrifugal blower. $\mathrm{O}_{3}$ was generated from pure oxygen by high-voltage electric discharge (Yuyao Shenglete Company, Zhejiang, China). A series of solenoid valves, linked online with a programmable log controller (PLC K80S, LG, LSIS, 
Gyeonggi-Do, Korea), were used to control the gas meters and provide oxygen based on the established relationship between the $\mathrm{O}_{3}$ concentrations within the OTCs and oxygen volume. The $\mathrm{O}_{3}$ concentrations within the OTCs were monitored by an $\mathrm{O}_{3}$ analyzer (Model 9810B, Teledyne Monitor Labs, Englewood, USA). A data logger $(21 \times(\mathrm{L})$, Campbell Scientific, Inc. Logan, Utah, USA) stored $\mathrm{O}_{3}$ concentration data and the temperature within the OTCs, which was measured with a constantan-copper thermocouple.

According to the monitoring of ambient $\mathrm{O}_{3}$ concentrations during March and May 2006 in the experimental site, the maximum instantaneous $\mathrm{O}_{3}$ concentration was $108 \mathrm{~nL} / \mathrm{L}$, maximum hourly average $\mathrm{O}_{3}$ concentration was $94 \mathrm{~nL} / \mathrm{L}$, maximum 8-hour average $\mathrm{O}_{3}$ concentration was $68 \mathrm{~nL} / \mathrm{L}$, and 8-hour average $\mathrm{O}_{3}$ concentration was $45 \mathrm{~nL} / \mathrm{L}$. Three different $\mathrm{O}_{3}$ exposure scenarios were employed, consisting of charcoal-filtered air alone (CK) and filtered air with the addition of two levels of daily changing $\mathrm{O}_{3}\left(\mathrm{O}_{3}-1\right.$ and $\left.\mathrm{O}_{3}-2\right)$. In the $\mathrm{O}_{3}-1$ treatment, the expected $\mathrm{O}_{3}$ changes were as follows: 9:00-10:00, $50 \mathrm{~nL} / \mathrm{L}$; 10:00-12:00, $100 \mathrm{~nL} / \mathrm{L} ; 12: 00-14: 00,150 \mathrm{~nL} / \mathrm{L} ; 14: 00-16: 00,100 \mathrm{~nL} / \mathrm{L}$; and 16:00-17:00, $50 \mathrm{~nL} / \mathrm{L}$. In $\mathrm{O}_{3}-2$, the same $\mathrm{O}_{3}$ change trend was used with higher concentrations of 100,150 , and $200 \mathrm{~nL} / \mathrm{L} . \mathrm{O}_{3}$ was generated from 9:00 to 17:00 local time. Nine chambers were used, providing three replicates for each of the three $\mathrm{O}_{3}$ treatments. The $\mathrm{O}_{3}$ treatments began on 26 March 2007, and were terminated on 19 May 2007, covering the period from the three-leaf stage until maturity. Because ambient $\mathrm{O}_{3}$ concentrations are generally low during extended rainy periods, fumigations were not carried out, and 30 full days of fumigation occurred. The AOT40 (accumulated exposure over a threshold of $40 \mathrm{ppb}$ or $\mathrm{nL} / \mathrm{L}$ ) values were 0,1585 , and $9172 \mathrm{ppb} \bullet \mathrm{h}$ for the treatments $\mathrm{CK}, \mathrm{O}_{3}-1$ and $\mathrm{O}_{3}-2$, respectively.

\subsection{Soil sampling}

On 13 May, samples of non-rhizosphere soil from the surface layer $(0-10 \mathrm{~cm})$ of the Chinese red soils were collected at random using $2 \mathrm{~cm}$ cores, with ten pooled soil cores at each OTC. The soil that remained adhered to the root hairs after gentle shaking was sampled as the rhizosphere soil, as classified by the operational definition (Lynch, 1990). Field moist soils were sieved to $<2 \mathrm{~mm}$, and large pieces of plant material and soil animals were removed before further analysis.

\subsection{Soil microorganism assessment}

\subsubsection{Microbial biomass}

The fumigation-extraction method (Vance et al., 1987) was used to determine the soil microbial biomass $\mathrm{C}$ of the soil samples. The content of $\mathrm{K}_{2} \mathrm{SO}_{4}$-extracted $\mathrm{C}$ from the $\mathrm{CHCl}_{3}$-treated and untreated soils was determined by an automated TOC analyzer.

1.5.2. Community-level physiological profiles (CLPPs) obtained by sole $\mathrm{C}$ source utilization tests

ECO plates, which are based on 31 different C sources and contain built-in triplicates for better replication, were employed in this study. Triplicate $10 \mathrm{~g}$ soil samples were combined with $90 \mathrm{~mL} 0.85 \%$ sterile $\mathrm{NaCl}$ solution and vibrated for $30 \mathrm{~min}$, and the $10^{-3}$ dilutions were then used to inoculate the Biolog plates. A $150 \mu \mathrm{L}$ dilution aliquot was inoculated into each well of a plate (Biolog Inc., Hayward, California, USA) and incubated at a constant $25^{\circ} \mathrm{C}$. The plates were scanned twice daily at $590 \mathrm{~nm}$ on a special reader for 10 days. The raw absorbance data for each reading was converted to net absorbance data by subtracting the control well reading. The average well color development (AWCD) for each plate reading was calculated by averaging all responses as a measure of total activity as follows.

$$
\mathrm{AWCD}=\sum(C-R) / n
$$

where, $C$ is the value of absorbance in every well with a carbon source; $R$ is the value of the absorbance in the blank well; and $n$ is 31 carbon sources. For different $C$ sources, $n$ has different values: according to category, the values are 10, 7, 6, 2, 4, and 2 for carbohydrates, carboxylic acids, amino acids, amides/amines, polymers and miscellaneous compounds, respectively (Choi and Dobbs, 1999). In this study, only three main types of compounds, carbohydrates, carboxylic acids and amino acids, were used to indicate microbial activity.

Microtiter wells with optical densities of 0.1 or greater were considered positive for determining Biolog richness (total number of positive wells). The Shannon-Wiener diversity index $\left(H^{\prime}\right)$ was calculated as follows:

$H^{\prime}=-\sum(P i \times \log P i)$

where, $\mathrm{Pi}=(C-R) / \sum(C-R)$. The functional richness index and diversity index were determined from the data gathered after $96 \mathrm{hr}$ of incubation.

\subsubsection{Ester-linked phospholipid fatty acid (PLFA) analysis}

PLFA analyses were performed using the modified Bligh and Dyer method (Frostegård et al., 1993), as described in Chen et al. (2010).

Known amounts of methyl nonadecanoate (19:0) were added before analysis by GC-MS. The total PLFA was calculated using 19:0 as the internal standard. The PLFA 18:2 $\omega 6,9$ was taken to indicate predominantly fungi. The PLFAs 18:0(10Me) and 19:0(10Me) were taken to indicate actinomycetes. The amount of bacterial PLFAs was calculated as the sum of the PLFAs 14:0, 15:0, a15:0, 16:0, i16:0, 16:l $\omega 7$, a17:0, 17:0, cy17:0, 18:0, 18:lw7, 18:109 and cy19:0, as according to Frostegård et al. (1996).

\subsection{Statistical analyses}

The $\mathrm{O}_{3}$ effects on microbial biomass C, AWCD, Biolog richness, and Shannon-Wiener diversity were tested by Analysis of Variance (ANOVA) using SPSS 11.5 (SPSS Inc., Chicago, llinois, USA). The LSD for the $95 \%$ confidence interval $\left(\mathrm{LSD}_{0.05}\right)$ was used for multiple comparisons. Student's t-test was used to compare the treatment means of microbial biomass $\mathrm{C}$, functional diversity indices, PLFA\% and the relative PLFA indicators. Differences were considered significant at $p \leq 0.05$. The values were normalized by dividing by the AWCD for the plate reading at $96 \mathrm{~h}$ of incubation, and these values were analyzed by principal component analysis (PCA). The PLFAs, expressed as percentages, were analyzed by PCA, and the effects of treatments on the different indicator PLFAs (\%) were 
tested by ANOVA using SPSS 11.5 (SPSS Inc., Chicago, lllinois, USA). In order to find if PCs could discriminate between the treatments, the scores of PCs were analyzed by ANOVA using SPSS 11.5 (SPSS Inc., Chicago, lllinois, USA).

\section{Results}

\subsection{Microbial biomass carbon}

In the $\mathrm{CK}$ and low $\mathrm{O}_{3}$ treatments, the microbial biomass of rhizosphere soil is higher than for non-rhizosphere soil. In the high $\mathrm{O}_{3}$ treatment, however, the microbial biomass of rhizosphere soil decreased rapidly, and that of the non-rhizosphere soil did not decrease much. No significant effects of $\mathrm{O}_{3}$ were observed on the microbial biomass $\mathrm{C}$ of non-rhizosphere soil under field-planted wheat, while both $\mathrm{O}_{3}$ treatments significantly reduced the soil microbial $\mathrm{C}$ of rhizosphere soil (by $16 \%$ for $\mathrm{O}_{3}-1$ and $50.7 \%$ for $\mathrm{O}_{3}-2$ ) compared to the control treatment (Table 1).

\subsection{Community level physiological profiles}

\subsubsection{Principal component analysis}

Principal component analyses were conducted to determine the microbial community structures of wheat soils under the different $\mathrm{O}_{3}$ treatments. PC1 and PC2 explained 38.4\% and $17.7 \%$ of the variance, respectively, and PC1 clearly discriminated between the treatments for rhizosphere soil $(F=20$, $p \leq 0.002$ for PC1); however, both PCs did not discriminate between the treatments for the non-rhizosphere soil (Fig. 1).

\subsubsection{Functional diversity indices}

In the $\mathrm{CK}$ and low $\mathrm{O}_{3}$ treatment, the functional diversity indices were similar between rhizosphere and non-rhizosphere soils, although the functional diversity indices were lower in rhizosphere than those in non-rhizosphere soil. High $\mathrm{O}_{3}$ treatment $\left(\mathrm{O}_{3}-2\right)$ significantly reduced the Shannon-Wiener diversity of both non-rhizosphere and rhizosphere soils, but $\mathrm{O}_{3}$ only had an evident effect on richness in the rhizosphere soil (Table 2).

\subsubsection{Utilization of main carbon sources}

$\mathrm{EO}_{3}$ had no effects on the three main $\mathrm{C}$ sources of nonrhizosphere soil under field-planted wheat. However, the high $\mathrm{O}_{3}$ treatment $\left(\mathrm{O}_{3}-2\right)$ had an obvious negative effect on the utilization of the main compounds compared to both the control and the low $\mathrm{O}_{3}$ treatments (Fig. 2).

Table 1-Microbial biomass carbon in rhizosphere and non-rhizosphere soil under different ozone treatments.

\begin{tabular}{lcc} 
Treatments & \multicolumn{2}{c}{ Microbial biomass (mg C/kg dry soil) } \\
\cline { 2 - 3 } & Non-rhizosphere soil & Rhizosphere soil \\
\hline $\mathrm{CK}$ & $468.60 \pm 1.6 \mathrm{a}$ & $594.20 \pm 14 \mathrm{a}$ \\
$\mathrm{O}_{3}-1$ & $468.10 \pm 12 \mathrm{a}$ & $499.50 \pm 29 \mathrm{~b}$ \\
$\mathrm{O}_{3}-2$ & $459.80 \pm 7 \mathrm{a}$ & $292.80 \pm 6.3 \mathrm{c}$ \\
\hline
\end{tabular}

Data are presented as means $\pm \mathrm{SE}(n=3)$.

Different letters within the column indicate significant differences among treatments $(p \leq 0.05)$.

\subsection{Ester-linked phospholipid fatty acid analysis}

\subsubsection{PLFA profile expression}

Sixteen total PLFAs, ranging from 14 to $19 \mathrm{Cs}$, were detected, including saturated, monounsaturated, polyunsaturated, branched and cyclopropyl fatty acids in all three treatments and both the rhizosphere and non-rhizosphere soils. The

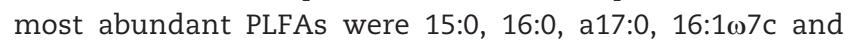
$18: 1 \omega 9 c$, which were characteristic of bacteria and comprised $60 \%$ of the total (Table 3 ).

\subsubsection{Principal component analysis}

In the field experiment, $57.7 \%$ of the total variance in the dataset was accounted for by PC 1 and $24.8 \%$ by PC 2, but only PC1 clearly discriminated among the PLFA profiles of non-rhizosphere soil from the different $\mathrm{O}_{3}$ treatments $(F=165, p \leq 0.001)$. For rhizosphere soil, the two principal components captured $55 \%$ and $28.5 \%$ of the total variance, respectively, and PC1 significantly discriminated among the PLFA profiles of the different $\mathrm{O}_{3}$ treatments $(F=12, p \leq 0.01)$ (Fig. 3).

\subsubsection{Distribution of microorganism groups}

The relative abundances of the microbial groups in the microbial community structure can be understood by examining the relative proportions of their characteristic fatty acids. The relative PLFA indicators of fungi, actinomycetes and bacteria can be calculated as percentages of the total. In non-rhizosphere soil, bacteria significantly increased and fungi increased after $\mathrm{O}_{3}$ exposure, while actinomycetes had no change. In rhizosphere soil, only high $\mathrm{O}_{3}$ treatment significantly increased bacteria and decreased fungi and actinomycetes (Table 4).

\section{Discussion}

$\mathrm{O}_{3}$ itself is a bactericide widely used for disinfection (Khurana, 2003). However, soil and vegetation remove $\mathrm{O}_{3}$ from the atmosphere, producing a vertical gradient of decreasing $\mathrm{O}_{3}$ concentrations towards the ground (Turner et al., 1974) and preventing any appreciable penetration of $\mathrm{O}_{3}$ into the soil (Blum and Tingey, 1977). Therefore, any direct effects of $\mathrm{O}_{3}$ on soil microorganisms can be of only minor importance, and the indirect effects of $\mathrm{O}_{3}$ on microbes arising from its impacts on plants are much more relevant. Among previous examinations of soil microbial communities, very few have considered rhizosphere soil microbial responses to $\mathrm{O}_{3}$. The rhizosphere is the microbial habitat in the soil that is most strongly influenced by plants (Dohrmann and Tebbe, 2005). In several studies, the composition of root exudates, which mainly serve as $C$ and energy sources for soil microorganisms (especially rhizosphere microbes), has been shown to strongly influence the structural and functional diversity of the microbial community (Kowalchuk et al., 2002; Miethling et al., 2000; Schmalenberger and Tebbe, 2003). $\mathrm{O}_{3}$ has also been shown to change the quantity and quality of root exudates (McCrady and Andersen, 2000), which primarily influence the microbial structure and function of the rhizosphere. In this study, the microbial community structures of both non-rhizosphere and rhizosphere soils were examined to determine if $\mathrm{O}_{3}$ had a greater effect in the rhizosphere. 

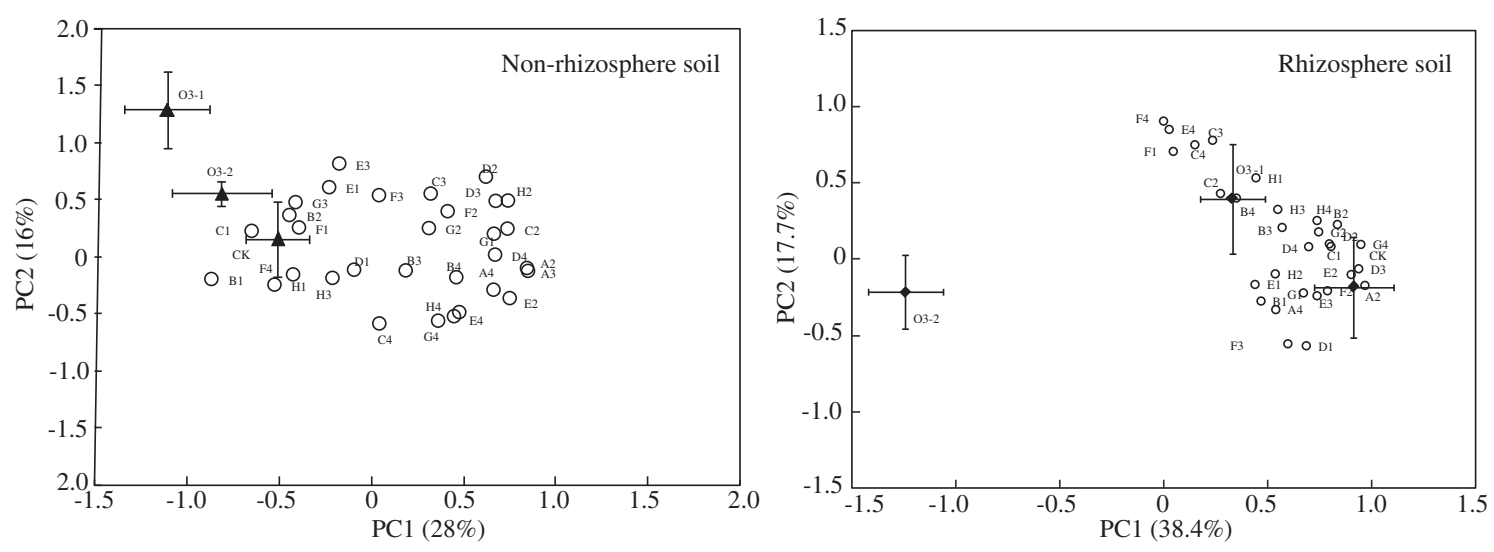

Fig. 1 - Biplot of soil microbial community structure generated by principal component analysis (PCA) of BIOLOG data under different ozone treatments. *The capital letter plus number indicates the corresponding substrate in ECO-plate with 8 lines (A-H) and 4 rows (1-4). A1, Water; A2, B-methyl-D-glucoside; A3, D-galactonic acid y-lactone; A4, L-arginine; B1, pyruvic acid methyl ester; B2, D-xylose; B3, D-galacturonic acid; B4, L-asparagine; C1, Tween 40; C2, I-erythritol; C3, 2-hydroxy benzoic acid; C4, L-phenylalanine; D1, Tween 80; D2, D-mannitol; D3, 4-hydroxy benzoic acid; D4, L-serine; E1, a-cyclodextrin; E2, N-acetyl-D-glucosamine; E3, y-hydroxybutyric acid; E4, L-threonine; F1, glycogen; F2, D-glucosaminic acid; F3, itaconic acid; F4, glycyl-L-glutamic acid; G1, D-cellobiose; G2, glucose-1-phosphate; G3, a-ketobutyric acid; G4, phenylethyl-amine; H1, a-D-lactose; H2, D,L-a-glycerol; H3, D-malic acid; H4, putrescine.

In our study, $\mathrm{eO}_{3}$ significantly reduced microbial biomass $\mathrm{C}$ in rhizosphere soil, but no effects of $\mathrm{O}_{3}$ on this variable were observed in non-rhizosphere soil. This result is coincident with the soil microbial biomass response to $\mathrm{eO}_{3}$ under potted wheat of the same species (T. aestivum L. Jia 002) (Chen et al., 2009). Another of our previous experiments also showed that $\mathrm{eO}_{3}$ reduced soil microbial $\mathrm{C}$ under rice (Chen et al., 2010). $\mathrm{O}_{3}$ significantly decreased soil microbial biomass in the fall, after one season of exposure, in a wheat (T. aestivum) and soybean (Glycine max) system (Islam et al., 2000). However, in ponderosa pine (Pinus ponderosa), the total fungal and bacterial biomasses increased at low $\mathrm{O}_{3}$ levels, and the total microbial biomass decreased at high $\mathrm{O}_{3}$ levels, compared to the biomasses under the control treatment (Scagel and Andersen, 1997). $\mathrm{O}_{3}$ has also been reported as having only slight effects on soil biomass in field-grown silver birch exposed to $\mathrm{eO}_{3}$ in OTCs for 3 years (Kasurinen et al., 2005). $\mathrm{O}_{3}$ may shift microbial structure without altering total microbial biomass, as has previously been found under $\mathrm{eCO}_{2}$ (Phillips et al., 2002). These inconsistent results require further investigation.

CLPP by sole C source utilization tests is a good method for assessing microbial community metabolic diversity using Biolog microplates (Garland, 1997). In this study, $\mathrm{eO}_{3}$ did not change the $\mathrm{C}$ utilization pattern of non-rhizosphere soil microorganisms, but did significantly impact the utilization pattern of rhizosphere microbes. The effect of $\mathrm{O}_{3}$ on the diversity index calculated from the Biolog plates was also significant in the rhizosphere soil, but not in the non-rhizosphere soil. $\mathrm{O}_{3}$ also reduced the utilization of the three main substrates in rhizosphere soil but had no effect in non-rhizosphere soil. The CLPP results showed that the soil microbial community under field-planted wheat responds in the same manner to $\mathrm{eO}_{3}$ as does that under potted wheat (Chen et al., 2009). All of these effects showed that $\mathrm{O}_{3}$ has much greater effects on rhizosphere soil carbon degradative microbes than on those of non-rhizosphere soil. This difference may be due to the decreased $\mathrm{C}$ exudates from the roots of the $\mathrm{O}_{3}$-exposed crop. The changes in root exudation may affect rhizosphere microbial activity, potentially altering the ecological and nutrient dynamics in the rhizosphere (Bardgett et al., 1999). Edwards' study showed that the exudation of organic compounds from the roots of $\mathrm{O}_{3}$-exposed plants declined due to the reduced translocation of photosynthate to the roots, thereby decreasing the nutrient supply to soil microorganisms and resulting in lower microbial metabolism (Edwards, 1991). The difference in utilization of $C$ sources suggests a change in substrate availability between the $\mathrm{CK}$ and $\mathrm{eO}_{3}$ treatments, as Biolog plates are capable of detecting changes in microbial community metabolic function resulting from actual C source availability (Grayston et al., 1998). The

Table 2 - Effects of ozone on soil microbial community functional richness and diversity.

\begin{tabular}{|c|c|c|c|c|}
\hline & \multicolumn{2}{|c|}{ Shannon-Weinner diversity } & \multicolumn{2}{|c|}{ Richness } \\
\hline & Non-rhizosphere soil & Rhizosphere soil & Non-rhizosphere soil & Rhizosphere soil \\
\hline $\mathrm{CK}$ & $1.34 \pm 0.01 \mathrm{a}$ & $1.32 \pm 0.01 a$ & $24.70 \pm 0.33 a$ & $24.00 \pm 1.15 a$ \\
\hline $\mathrm{O}_{3}-1$ & $1.31 \pm 0.02 \mathrm{ab}$ & $1.32 \pm 0.01 \mathrm{a}$ & $23.00 \pm 1.53 a$ & $24.70 \pm 1.20 \mathrm{a}$ \\
\hline $\mathrm{O}_{3}-2$ & $1.28 \pm 0.01 b$ & $1.19 \pm 0.03 b$ & $22.00 \pm 0.00 \mathrm{a}$ & $18.3 .0 \pm 0.67 b$ \\
\hline
\end{tabular}




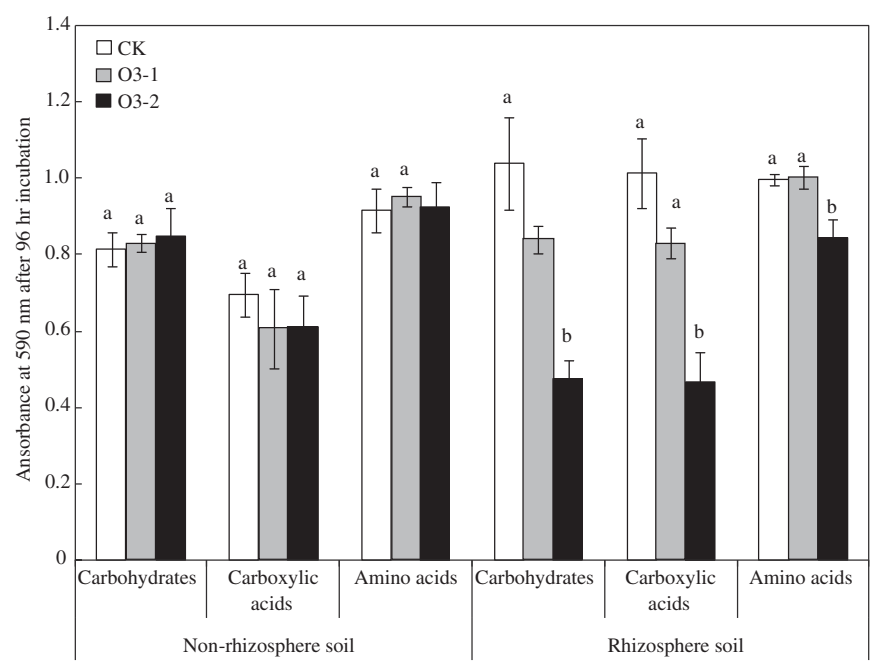

Fig. 2 - The effect of ozone on utilization of three main carbon sources of non-rhizosphere soil and rhizosphere soil under field wheat. Bars with different letters indicate differences $(p \leq 0.05)$ between treatments within each main carbon source in non-rhizosphere or rhizosphere soil. The vertical thin bars are stand errors at $95 \%$ confidence intervals.

results from the $\mathrm{C}$ utilization experiments showed that rhizosphere soil microorganisms used fewer carbohydrates, carboxylic acids and amino acids under $\mathrm{eO}_{3}$, which may be attributed to the reduced exudation of these compounds from the roots when the

\begin{tabular}{|c|c|c|c|c|c|c|}
\hline \multirow[t]{2}{*}{ PLFA $^{a}$} & \multicolumn{3}{|c|}{ Rhizosphere soil } & \multicolumn{3}{|c|}{ Non-rhizosphere soil } \\
\hline & CK & $\mathrm{O}_{3}-1$ & $\mathrm{O}_{3}-2$ & CK & $\mathrm{O}_{3}-1$ & $\mathrm{O}_{3}-2$ \\
\hline 14:0 & $3.73 a$ & $2.27 \mathrm{~b}$ & $2.75 b$ & $3.20 \mathrm{a}$ & $0.00 c$ & $2.45 b$ \\
\hline 15:0 & $10.83 \mathrm{~b}$ & $11.28 \mathrm{a}$ & $11.43 a$ & $10.89 b$ & $8.88 c$ & $12.12 \mathrm{a}$ \\
\hline $16: 0$ & 14.07 & 15.98 & 15.97 & 13.21 & 11.29 & 15.14 \\
\hline $17: 0$ & 3.12 & 2.67 & 3.21 & 3.14 & 3.27 & 2.61 \\
\hline 18:0 & $2.76 \mathrm{~b}$ & $1.86 \mathrm{c}$ & $3.61 a$ & $1.65 b$ & $2.59 \mathrm{ab}$ & $3.07 a$ \\
\hline i14:0 & 0.00 & 0.00 & 0.00 & $0.00 \mathrm{~b}$ & $2.35 a$ & $0.00 \mathrm{~b}$ \\
\hline a15:0 & 6.65 & 7.01 & 7.09 & $6.20 \mathrm{a}$ & $4.52 b$ & $7.05 a$ \\
\hline i16:0 & $6.40 \mathrm{a}$ & $5.68 \mathrm{ab}$ & $5.02 b$ & $5.40 \mathrm{a}$ & $3.86 \mathrm{~b}$ & $5.67 a$ \\
\hline a17:0 & $10.95 a$ & $10.00 \mathrm{~b}$ & $10.08 \mathrm{~b}$ & $12.10 \mathrm{~b}$ & $26.07 a$ & $10.71 \mathrm{~b}$ \\
\hline $16: 1 \omega 7 c$ & $13.98 a$ & $12.62 b$ & $11.21 \mathrm{c}$ & 9.66 & 10.16 & 11.70 \\
\hline 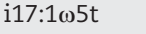 & $0.00 \mathrm{~b}$ & $3.13 a$ & $2.86 a$ & $3.45 a$ & $0.00 \mathrm{~b}$ & $2.92 a$ \\
\hline $18: 1 \omega 7 t$ & $1.28 \mathrm{a}$ & $0.00 \mathrm{~b}$ & $0.00 \mathrm{~b}$ & 0.00 & 0.00 & 0.00 \\
\hline $18: 1 \omega 9 c$ & $10.98 c$ & $12.61 \mathrm{~b}$ & $14.46 a$ & $12.59 a$ & $10.45 b$ & $13.73 a$ \\
\hline cy17:0 & $5.04 a$ & $4.52 b$ & $2.72 c$ & $4.22 \mathrm{a}$ & $2.97 b$ & $2.68 \mathrm{~b}$ \\
\hline cy19:0 & 2.52 & 2.47 & 2.72 & 2.84 & 2.81 & 2.85 \\
\hline 18:0(10Me) & $2.91 \mathrm{a}$ & $3.13 a$ & $1.54 b$ & $3.28 \mathrm{ab}$ & $4.07 a$ & $2.03 b$ \\
\hline 19:0(10Me) & $2.39 c$ & $2.60 \mathrm{~b}$ & $2.81 \mathrm{a}$ & $2.19 b$ & $1.82 \mathrm{c}$ & $2.71 a$ \\
\hline $18: 2 \omega 6,9$ & 2.36 & 2.16 & 2.54 & 3.09 & 4.90 & 2.56 \\
\hline
\end{tabular}

Different letters within the row indicate significant differences among treatments $(p \leq 0.05)$.

${ }^{a}$ Fatty acids are designated in terms of the total number of $C$ atoms: number of double bonds, followed by the position of the double bond from the methyl end of the molecule. Cis and trans configurations are indicated by $c$ and $t$, respectively. The prefixes $a$ and $i$ indicate anteiso and iso branching, br indicates an unknown methyl branching position, 10Me indicates a methyl group on the 10th $\mathrm{C}$ atom from the carboxyl end of the molecule, and cy refers to cyclopropane fatty acids. crops were exposed to $\mathrm{eO}_{3}$ concentrations. Indeed, $\mathrm{McCool}$ and Menge (1983) have found that $\mathrm{O}_{3}$ treatment decreases the amount of sugars and amino acids in root exudates.

CLPP is a simple and economical method for investigating carbon degradative microbes, but it has the disadvantages of being biased by cultural conditions and failing to consider the contributions of fungi and slow-growing bacteria (Smalla et al., 1998), which the PLFA method does not miss (Bååth et al., 1998; White and MacNaughton, 1997). Biolog plates present functional rather than structural information about the soil microbial community (Bossio and Scow, 1998), while PLFA results can express both structural and quantitative information (Yao et al., 2000). The relative abundances of the microbial groups in the microbial community structure can be understood by examining the relative proportions of their characteristic fatty acids (Bossio and Scow, 1998). In this study, the PLFA method was also used to investigate the effects of $\mathrm{O}_{3}$ on microbial community structure.

The bacterial indicator PLFAs were the most abundant in the rhizosphere and non-rhizosphere soils. The patterns of the PLFA profiles were significantly different between the three $\mathrm{O}_{3}$ treatments in both the rhizosphere and non-rhizosphere soils. After the wheat was exposed to $\mathrm{O}_{3}$, the relative abundances of fungi and actinomycetes decreased, and the relative abundance of bacteria increased. These observations are consistent with the results from an experimental platform of free-air $\mathrm{O}_{3}$ enrichment in which fungal PLFA and the fungi to bacteria ratio decreased following exposure to $\mathrm{eO}_{3}$, especially in the rhizosphere soil of $\mathrm{O}_{3}$-tolerant wheat (Li et al., 2012). Active bulk soil fungal biomass and the ratio of active fungal to active bacterial biomass increased with increasing exposure to $\mathrm{O}_{3}$ in ponderosa pine (P. ponderosa) (Scagel and Andersen, 1997). In another study, the relative proportions of gram-positive and gram-negative indicator PLFAs of bulk soil beneath aspen, birch, and maple trees (Poplus tremuloides Michx., Betula papyrifera Marsh., and Acer saccharum Marsh.) were not affected after incubation at elevated levels of tropospheric $\mathrm{O}_{3}$ over a period of 

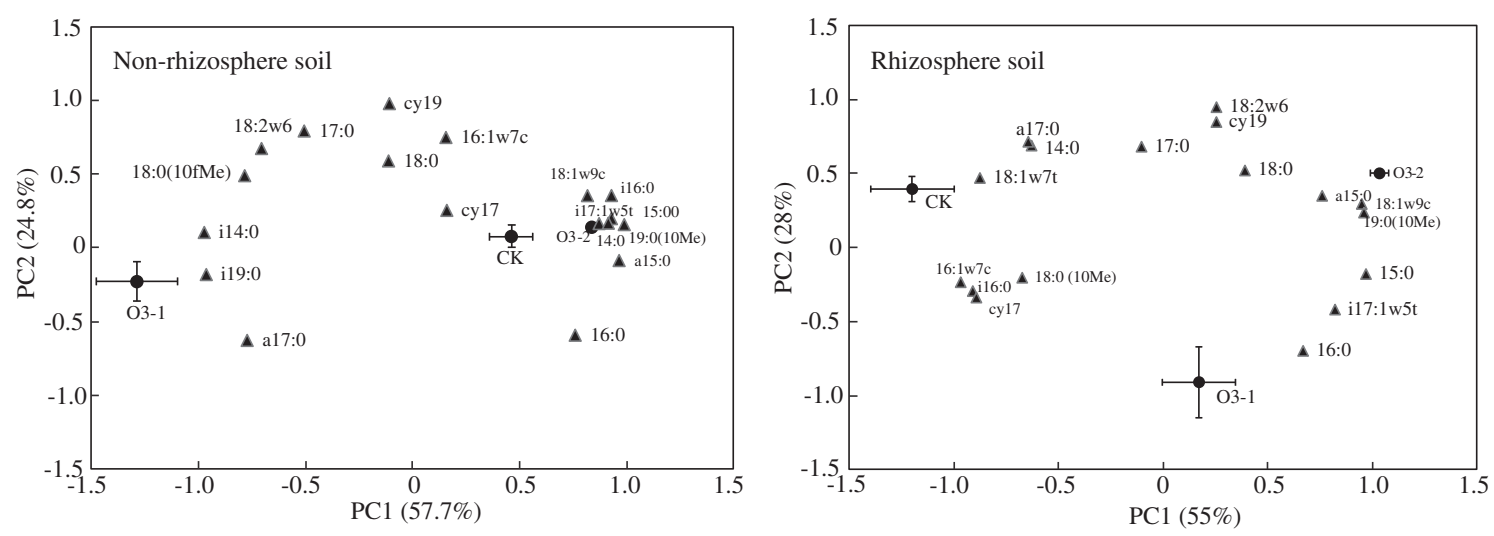

Fig. 3 - Biplot of soil microbial community structure generated by principal component analysis (PCA) of PLFA data under different ozone treatments. Fatty acids are designated in terms of the total number of $\mathrm{C}$ atoms:number of double bonds, followed by the position of the double bond from the methyl end of the molecule. Cis and trans configurations are indicated by $c$ and $t$, respectively. The prefixes $a$ and $i$ indicate anteiso and iso branching, br indicates an unknown methyl branching position, 10Me indicates a methyl group on the 10th C atom from the carboxyl end of the molecule, and cy refers to cyclopropane fatty acids.

3 years (Phillips et al., 2002). In contrast, the abundance of fungal PLFAs in the same study declined with $\mathrm{eO}_{3}$ beneath aspen and aspen-birch, while $\mathrm{O}_{3}$ did not reduce fungal abundance beneath aspen-maple. This result indicated that fungi are possibly more responsive in the soil of $\mathrm{O}_{3}$-stressed early-successional tree species than are bacteria. This minor effect of $\mathrm{O}_{3}$ on bacteria was corroborated by a study of the bacterial community inhabiting the rhizospheres of herbaceous plants after exposure to $\mathrm{eO}_{3}$, which the authors considered to have a surprisingly small effect on the structural diversity of the bacterial community (Dohrmann and Tebbe, 2005). In that study, genetic profiling based on single-strand conformation polymorphisms (SSCP) revealed that the different SSCP profiles generated from the bacterial community of the rhizospheres from $\mathrm{O}_{3}$-stressed and control plants were very similar and were not distinguished by statistical methods, which indicated that elevated levels of $\mathrm{O}_{3}$ did not select for a different bacterial community composition. He et al. (2013) also analyzed 96 soil samples from a soybean free-air $\mathrm{CO}_{2}$ enrichment (SoyFACE) experimental site using a comprehensive functional gene microarray (GeoChip 3.0, MWG Biotech Inc., High Point, North Carolina, USA). The results showed that the overall functional composition and structure of the soil microbial community shifted under $\mathrm{eO}_{3}$. Key functional genes involved in $\mathrm{C}$ fixation, nitrogen fixation, denitrification and $\mathrm{N}$ mineralization were suppressed under $\mathrm{eO}_{3}$, and those involved in $\mathrm{C}$ degradation and $\mathrm{CH}_{4}$ generation remained unchanged under $\mathrm{eO}_{3}$ (He et al., 2013). These variable responses of the microbial community to $\mathrm{eO}_{3}$ may be attributed to numerous factors, including different species, different levels of $\mathrm{O}_{3}$ exposure and different sampling procedures at different growth stages.

The results of the present study showed that $\mathrm{eO}_{3}$ had similar effects on the soil microbial community under field and potted wheat (Chen et al., 2009), but some differences were observed between the field and potted experiments. The soil microbial biomass $\mathrm{C}$ in the field-planted wheat was much higher than that in the potted wheat, and the utilization of $C$ sources in the field-planted wheat was also higher. Additionally, fungal indicator PLFAs were not detected in non-rhizosphere soil in the potted experiment. In the potted wheat study, the AOT40 values for the two $\mathrm{eO}_{3}$ treatments were $21.4 \mathrm{ppm} \bullet \mathrm{h}$ and $44.1 \mathrm{ppm} \bullet \mathrm{h}$, respectively, for $\mathrm{O}_{3}-1$ and $\mathrm{O}_{3}-2$, which were much higher than the levels for $\mathrm{O}_{3}-1$ (1.59 ppm $\left.\bullet \mathrm{h}\right)$ and $\mathrm{O}_{3}-2(9.17 \mathrm{ppm} \bullet \mathrm{h})$ employed in this field study. However, the effects of $\mathrm{eO}_{3}$ on the soil microbial community in the field experiment were considerably more significant than in the pot experiment. The pot experiment may therefore have masked the real harm of $\mathrm{eO}_{3}$ to vegetation. The effects of $\mathrm{eO}_{3}$ on soil microbes were definitely especially prominent in rhizosphere soil, which means that $\mathrm{O}_{3}$ affects the soil food web through the roots. In addition, the effect area is

Table 4 - The effect of ozone on soil microbial community composition under wheat (expressed as \% of total PLFA).

\begin{tabular}{|c|c|c|c|c|c|c|}
\hline & \multicolumn{3}{|c|}{ Non-rhizosphere soil } & \multicolumn{3}{|c|}{ Rhizosphere soil } \\
\hline & Bacteria & Actinomycete & Fungi & Bacteria & Actinomycete & Fungi \\
\hline $\mathrm{CK}$ & $88.54 \pm 1.16 b$ & $5.47 \pm 0.04$ & $3.09 \pm 0.02 \mathrm{a}$ & $91.81 \pm 0.50 b$ & $5.63 \pm 0.23 a$ & $2.86 \pm 0.07 a$ \\
\hline $\mathrm{O}_{3}-1$ & $91.72 \pm 1.01 \mathrm{a}$ & $5.89 \pm 0.80$ & $2.40 \pm 0.21 b$ & $91.61 \pm 0.22 b$ & $5.73 \pm 0.09 a$ & $2.66 \pm 0.14 \mathrm{ab}$ \\
\hline $\mathrm{O}_{3}-2$ & $93.03 \pm 0.17 a$ & $4.74 \pm 0.01$ & $2.22 \pm 0.17 \mathrm{~b}$ & $93.10 \pm 0.04 a$ & $4.36 \pm 0.05 b$ & $2.54 \pm 0.01 b$ \\
\hline
\end{tabular}


limited, and further study is needed to determine whether the limited effect of $\mathrm{O}_{3}$ on rhizosphere soil microbes would affect the nutrient utilization of vegetation.

\section{Conclusions}

This study showed that there is significant alteration in microbial biomass and community functions in rhizosphere soil, but not in rhizosphere soil, under $\mathrm{eO}_{3}$ exposure. In addition, the microbial community structure of rhizosphere soil responds more significantly to $\mathrm{eO}_{3}$ than non-rhizosphere soil. This strongly suggests that the effects detected in the rhizosphere microbial community came about due to the ozone effects on the plant, not as direct effects of ozone on the rhizosphere microbes. However, there are still some problems in this study. OTC can produce microclimates which might not reflect the real reaction of plant vegetation to $\mathrm{O}_{3}$. Recent advances in molecular biological methods could provide more sophisticated tools to study the microbial community response to $\mathrm{O}_{3}$ than the CLPP and PLFA methods used here. Many uncertainties remain in the soil microbial community response to $\mathrm{O}_{3}$ stress. Long-term experiments should be carried on in order to determine if the $\mathrm{O}_{3}$ impacts on the soil are accumulative.

\section{Acknowledgments}

This work was supported by the National Natural Science Foundation of China (No. 30670387), the Ministry of Environmental Protection (No. 200809152), and the Key Project of the Chinese Academy of Sciences (No. KZCXZ-YW-422-3).

\section{R E F E R E N C E S}

Andersen, C.P., 2003. Source-sink balance and carbon allocation below ground in plants exposed to ozone. New Phytol. 157 (2), 213-228.

Bååth, E., Díaz-Raviña, M., Frostegård, Å., Campbell, C.D., 1998. Effect of metal-rich sludge amendments on the soil microbial community. Appl. Environ. Microbiol. 64 (1), 238-245.

Bardgett, R.D., Lovell, R.D., Hobbs, P.J., Jarvis, S.C., 1999. Seasonal changes in soil microbial communities along a fertility gradient of temperate grasslands. Soil Biol. Biochem. 31 (7), 1021-1030.

Blum, U., Tingey, D.T., 1977. Study of potential ways in which ozone could reduce root-growth and nodulation of soybean. Atmos. Environ. 11 (8), 737-739.

Bossio, D.A., Scow, K.M., 1998. Impacts of carbon and flooding on soil microbial communities: phospholipid fatty acid profiles and substrate utilization patterns. Microb. Ecol. 35 (3-4), 265-278.

Bytnerowicz, A., Omasa, K., Paoletti, E., 2007. Integrated effects of air pollution and climate change on forests: a northern hemisphere perspective. Environ. Pollut. 147 (3), 438-445.

Chen, Z., Wang, X.K., Feng, Z.Z., Zheng, F.X., Duan, X.N., Yang, W.R., 2008. Effects of elevated ozone on growth and yield of field-grown rice in Yangtze River Delta, China. J. Environ. Sci. 20 (3), 320-325.

Chen, Z., Wang, X.K., Feng, Z.Z., Xiao, Q., Duan, X.N., 2009. Impact of elevated $\mathrm{O}_{3}$ on soil microbial community function under wheat crop. Water, Air, Soil Pollut. 198 (1-4), 189-198.
Chen, Z., Wang, X.K., Yao, F.F., Zheng, F.X., Feng, Z.Z., 2010. Elevated ozone changed soil microbial community in a rice paddy. Soil Sci. Soc. Am. J. 74 (3), 829-837.

Chen, P.F., Quan, J.N., Zhang, Q., Tie, X.X., Gao, Y., Li, X., et al., 2013. Measurements of vertical and horizontal distributions of ozone over Beijing from 2007-2010. Atmos. Environ. 74, $37-44$.

Choi, K.H., Dobbs, F.C., 1999. Comparison of two kinds of Biolog microplates (GN and ECO) in their ability to distinguish among aquatic microbial communities. J. Microbiol. Methods 36 (3), 203-213.

Derwent, R.G., Simmonds, P.G., Manning, A.J., Spain, T.G., 2007. Trends over a 20-year period from 1987-2007 in surface ozone at the atmospheric research station, Mace Head, Ireland. Atmos. Environ. 41 (39), 9091-9098.

Dohrmann, A.B., Tebbe, C.C., 2005. Effects of elevated tropospheric ozone on the structure of bacterial communities inhabiting the rhizosphere of herbaceous plants native to Germany. Appl. Environ. Microbiol. 71 (12), 7750-7758.

Edwards, N.T., 1991. Root and soil respiration responses to ozone in Pinus taeda L. seedlings. New Phytol. 118 (2), 315-321.

Feng, Z.Z., Zheng, H.Q., Wang, X.K., Zheng, Q.W., Feng, Z.W., 2008. Sensitivity of Metasequoia glyptostroboides to ozone stress. Photosynthetica 46 (3), 463-465.

Feng, Z., Kobayashi, K., Wang, X., Feng, Z., 2009. A meta-analysis of responses of wheat yield formation to elevated ozone concentration. Chin. Sci. Bull. 54 (2), 249-255.

Frostegård, Å., Bååth, E., Tunlid, A., 1993. Shifts in the structure of soil microbial communities in limed forests as revealed by phospholipid fatty acid analysis. Soil Biol. Biochem. 25 (6), 723-730.

Frostegård, Å., Tunlid, A., Bååth, E., 1996. Changes in microbial community structure during long-term incubation in two soils experimentally contaminated with metals. Soil Biol. Biochem. 28 (1), 55-63.

Garland, J.L., 1997. Analysis and interpretation of community-level physiological profiles in microbial ecology. FEMS Microbiol. Ecol. 24 (4), 289-300

Grayston, S.J., Campbell, C.D., Lutze, J.L., Gifford, R.M., 1998. Impact of elevated $\mathrm{CO}_{2}$ on the metabolic diversity of microbial communities in N-limited grass swards. Plant Soil 203 (2), 289-300.

He, Z., Xiong, J., Kent, A.D., Deng, Y., Xue, K., Wang, G., et al., 2013. Distinct responses of soil microbial communities to elevated $\mathrm{CO}_{2}$ and $\mathrm{O}_{3}$ in a soybean agro-ecosystem. ISME J. 8 (3), 714-726.

Islam, K.R., Mulchi, C.L., Ali, A.A., 2000. Interactions of tropospheric $\mathrm{CO}_{2}$ and $\mathrm{O}_{3}$ enrichments and moisture variations on microbial biomass and respiration in soil. Glob. Chang. Biol. 6 (3), 255-265.

Kanerva, T., Palojärvi, A., Rämö, K., Manninen, S., 2008. Changes in soil microbial community structure under elevated tropospheric $\mathrm{O}_{3}$ and $\mathrm{CO}_{2}$. Soil Biol. Biochem. 40 (10), 2502-2510.

Kasurinen, A., Keinanen, M.M., Kaipainen, S., Nilsson, L.O., Vappavuori, E., Kontro, M.H., et al., 2005. Belowground responses of silver birch trees exposed to elevated $\mathrm{CO}_{2}$ and $\mathrm{O}_{3}$ levels during three growing seasons. Glob. Chang. Biol. 11 (7), 1167-1179.

Khurana, A., 2003. Ozone Treatment for Prevention of Microbial Growth in Air Conditioning Systems. (A thesis for the degree of master of engineering). University of Florida, Florida.

Kogel-Knabner, I., 2002. The macromolecular organic composition of plant and microbial residues as inputs to soil organic matter. Soil Biol. Biochem. 34 (2), 139-162.

Kowalchuk, G.A., Buma, D.S., de Boer, W., Klinkhamer, P.G.L., van Veen, J.A., 2002. Effects of above-ground plant species composition and diversity on the diversity of soil-borne microorganisms. Anton Leeuw. 81 (1-4), 509-520.

Li, Q., Bao, X.L., Lu, C.Y., Zhang, X.K., Zhu, J.G., Jiang, Y., et al., 2012. Soil microbial food web responses to free-air ozone enrichment can depend on the ozone-tolerance of wheat cultivars. Soil Biol. Biochem. 47, 27-35. 
Li, X.Y., Deng, Y., Li, Q., Lu, C.Y., Wang, J.J., Zhang, H.W., et al., 2013. Shifts of functional gene representation in wheat rhizosphere microbial communities under elevated ozone. ISME J. 7 (3), 660-671.

Lynch, J.M., 1990. The Rhizosphere. Wiley, New York, N.Y. Manninen, S., Aaltonen, H., Kanerva, T., Rämö, K., Paljärvi, A., 2010. Plant and soil microbial biomass in Agrostis capillaris and Lathyrus pratensis monocultures exposed to elevated $\mathrm{O}_{3}$ and $\mathrm{CO}_{2}$ for three growing seasons. Soil Biol. Biochem. 42 (11), 1967-1975.

McCool, P.M., Menge, J.A., 1983. Influence of ozone on carbon partitioning in tomato: potential role of carbon flow in regulation of the mycorrhizal symbiosis under conditions of stress. New Phytol. 94 (2), 241-247.

McCrady, J.K., Andersen, C.P., 2000. The effect of ozone on below-ground carbon allocation in wheat. Environ. Pollut. 107 (3), 465-472.

Miethling, R., Wieland, G., Backhaus, H., Tebbe, C.C., 2000. Variation of microbial rhizosphere communities in response to crop species, soil origin, and inoculation with Sinorhizobium meliloti L33. Microb. Ecol. 40 (1), 43-56.

Niu, J.F., Zhang, W.W., Feng, Z.Z., Wang, X.K., Tian, Y., 2011. Impact of elevated $\mathrm{O}_{3}$ on visible foliar symptom, growth and biomass of Cinnamomum camphora seedlings under different nitrogen loads. J. Environ. Monit. 13 (10), 2873-2879.

Paoletti, E., 2007. Ozone Impacts on Forests. CAB Reviews: Perspectives in Agriculture, Veterinary Science, Nutrition and Natural Resources. 2, No.068.

Phillips, R.L., Zak, D.R., Holmes, W.E., White, D.C., 2002. Microbial community composition and function beneath temperate trees exposed to elevated atmospheric carbon oxide and ozone. Oecologia 131 (2), 236-244.

Scagel, C.F., Andersen, C.P., 1997. Seasonal changes in root and soil respiration of ozone-exposed ponderosa pine (Pinus ponderosa) grown in different substrates. New Phytol. 136 (4), 627-643.

Schmalenberger, A., Tebbe, C.C., 2003. Genetic profiling of noncultivated bacteria from the rhizospheres of sugar beet (Beta vulgaris) reveal field and annual variability but no effect of a transgenic herbicide resistance. Can. J. Microbiol. 49 (1), 1-8.
Serengil, Y., Augustaitis, A., Bytnerowicz, A., Grulke, N., Kozovitz, A.R., Matyssek, R., et al., 2011. Adaptation of forest ecosystems to air pollution and climate change: a global assessment on research priorities. Forest 4, 44-48.

Smalla, K., Wachtendorf, U., Heuer, H., Liu, W.T., Forney, L., 1998. Analysis of BIOLOG GN substrate utilization patterns by microbial communities. Appl. Environ. Microbiol. 64 (4), 1220-1225.

Turner, N.C., Waggoner, P.E., Riche, S., 1974. Removal of ozone from atmosphere by soil and vegetation. Nature 250 (5466), 486-489.

Vance, E.D., Brookes, P.C., Jenkinson, D.S., 1987. An extraction method for measuring soil microbial biomass. Soil Biol. Biochem. 19 (19), 703-707.

Vingarzan, R., 2004. A review of surface ozone background levels and trends. Atmos. Environ. 38 (21), 3431-3442.

White, D.C., MacNaughton, S.J., 1997. Chemical and molecular approaches for rapid assessment of the biological status of soils. In: Pankhurst, C.E., Doube, B.M., Gupta, V.V.S.R. (Eds.), Biological Indicators of Soil Health. CAB International, pp. 371-396.

Wilkinson, S., Mills, G., Illidge, R., Davies, W.J., 2012. How is ozone pollution reducing our food supply? J. Exp. Bot. 63 (2), 527-536.

Yao, H., He, Z., Wilson, M.J., Campbell, C.D., 2000. Microbial biomass and community structure in a sequence of soils with increasing fertility and changing land use. Microb. Ecol. 40 (3), 223-237.

Zhang, W.W., Niu, J.F., Wang, X.K., Tian, Y., Yao, F.F., Feng, Z.Z., 2011. Effects of ozone exposure on growth and photosynthesis of the seedlings of Liriodendron chinense (Hemsl.) Sarg, a native tree species of subtropical China. Photosynthetica 49 (1), 29-36.

Zheng, Y., Stevenson, K.J., Barrowcliffe, R., Chen, S., Wang, H., Barnes, J.D., 1998. Ozone levels in Chongqing: a potential threat to crop plants commonly grown in the region? Environ. Pollut. 99 (3), 299-308. 